\title{
Growth hormone responses to growth hormone-releasing hormone and hexarelin in fed and fasted dogs: effect of somatostatin infusion or pretreatment with pirenzepine
}

\author{
A E Rigamonti, N Marazzi, S G Cella, L Cattaneo and E E Müller \\ Department of Medical Pharmacology, University of Milan, via Vanvitelli 32, 20129 Milan, Italy \\ (Requests for offprints should be addressed to E E Müller, Department of Medical Pharmacology, University of Milan, via Vanvitelli 32, 20129 Milan, Italy)
}

\begin{abstract}
Using unanesthetized young male and female beagle dogs, before and after a 2-day fast, we studied the effect of an i.v. infusion of $0.9 \%$ saline $(5 \mathrm{ml} / \mathrm{h})$, somatostatin (SS, 4 or $8 \mu \mathrm{g} / \mathrm{kg} / \mathrm{h}$ ) or pretreatment with pirenzepine (PZ, $0.6 \mathrm{mg} / \mathrm{kg}$ i.v.), a muscarinic cholinergic antagonist which allegedly releases $\mathrm{SS}$, on the $\mathrm{GH}$ release evoked by acute administration of GHRH $(2 \mu \mathrm{g} / \mathrm{kg}$ i.v.), hexarelin (HEXA), a member of the GH-releasing peptide family $(250 \mu \mathrm{g} / \mathrm{kg}$ i.v.) or GHRH plus HEXA.

In fasted dogs, GHRH delivered during saline infusion induced a clear-cut rise in plasma GH levels, significantly higher than that which it induced in fed dogs. In contrast, HEXA, although very effective in causing the release of $\mathrm{GH}$, only slightly increased $\mathrm{GH}$ secretion in fasted dogs over that which it induced in fed dogs. Co-administration of GHRH plus HEXA into fed dogs induced a synergic $\mathrm{GH}$ response that further increased with fasting.

The action of GHRH in fed dogs was abolished by the lower dose of SS, whereas SS at either dose was ineffective in suppressing the GH-releasing effect during fasting. Infusion of the lower dose of SS failed to counter the action of HEXA, either before or during fasting, whilst the higher SS dose partially reduced it in both conditions.

In contrast to SS, PZ reduced the GH-releasing effect of GHRH and HEXA, both in the fed state and, though to
\end{abstract}

a lesser extent, during fasting. Pirenzepine only slightly reduced the robust $\mathrm{GH}$ rise elicited by GHRH plus HEXA in fed dogs. The suppressive effect of PZ on the $\mathrm{GH}$ response to combined administration of the peptides was lowest in fasted dogs.

These data show that: (1) fasting augmented the GH response to GHRH and (to a lesser degree) to HEXA; (2) SS inhibited the GH response to GHRH in the fed state, but not in the fasted state; (3) only the higher dose of SS partially reduced the GH stimulation by HEXA in either the fed or the fasted state; (4) PZ lowered the GH response to GHRH and to HEXA in both the fed and (to a lesser degree) the fasted state; (5) PZ did not modify the $\mathrm{GH}$ release due to the combined administration of GHRH and HEXA.

It is suggested that: (1) during fasting the greatly enhanced GH response to GHRH alone or GHRH plus HEXA probably reflects an augmented GHRH secretion; (2) somatotrope refractoriness to SS may contribute to the enhanced GH secretion in states of calorie deprivation; (3) in contrast to a general belief, muscarinic cholinergic antagonists, e.g. PZ, do not act exclusively via release of SS, but probably also through inhibition of GHRH function.

Journal of Endocrinology (1998) 156, 341-348

\section{Introduction}

Growth hormone $(\mathrm{GH})$ secretion is under the regulatory control of the central nervous system (CNS) through two specific hypothalamic neuropeptides, GH-releasing hormone (GHRH) and somatostatin (SS). In addition, a complex network of neurotransmitters and hormonal, metabolic, nutritional and environmental stimuli regulate GH secretion by modulating either GHRH or SS secretion from the hypothalamus or by acting directly on the pituitary (Müller 1987).

Besides GHRH, a new class of small GH-releasing peptides (GHRPs) has been characterized (Bowers et al.
1984, 1990, 1992, Ilson et al. 1989, Walker et al. 1990, Hartman et al. 1992a). One of the most effective GHRPs is hexarelin (HEXA), which stimulates GH secretion in vitro and in vivo in a number of animal species, including man (Deghenghi et al. 1994, Ghigo et al. 1994, Cella et al . 1995).

Experimental evidence supports the existence of different regulation for GHRH and GHRPs. It includes: different receptors (Goth et al. 1992) and post-receptor mechanisms (Lussier et al. 1991, Akman et al. 1993) at the pituitary level; opposite GH responses following estrogen or dexamethasone treatment (Molla et al. 1993); different responsiveness to SS (Arvat et al. 1995); diverging 
modulation by indirect cholinergic agonists (Arvat et al. 1995). The mechanism(s) underlying such differences are, however, still obscure.

Both protein calorie restriction and fasting induce a $\mathrm{GH}$ hypersecretory state (Müller et al. 1995), which is suited to unravel the different regulation and the roles of GHRH and GHRPs. Reportedly the GHRH-induced GH response is greatly enhanced in humans (Rolla et al. 1986) and dogs (Arce et al. 1991) during calorie restriction. Thus, we first sought to probe the GH releasing effect of acute administration of GHRH, HEXA or GHRH plus HEXA in fed or short-term fasted dogs. We then studied the postulated defect of the hypothalamic somatostatinergic function (Müller et al. 1995) or a possible alteration of the pituitary responsiveness to SS (Bruno et al. 1994) during fasting, by testing GHRH and/or HEXA action in fed and fasted dogs under SS infusion.

Previous studies in calorie-restricted dogs (Arce et al. 1991) or patients with anorexia nervosa (AN) (Tamai et al. 1990, Rolla et al. 1991) had shown partial preservation of the $\mathrm{GH}$ response to GHRH despite pretreatment with pirenzepine (PZ), a muscarinic cholinergic antagonist and alleged hypothalamic SS releaser (Müller 1987). Thus, we finally evaluated the GH responses to GHRH and/or HEXA in fed and fasted dogs following PZ pretreatment.

\section{Materials and Methods}

\section{Animals}

Ten young beagle dogs ( 2 to 3 years old, 4 male and 6 female) were used in this study. They were well trained to lie on a comfortable pad in the laboratory for up to four hours at a time. Animals were fed normal dry food (Diete Standard, Charles River, Calco, Italy) once a day at $1600 \mathrm{~h}$, with water available ad libitum. They were kept under a 12-h light:12-h darkness regimen, with lights on at $0700 \mathrm{~h}$. At the beginning of the study body weights of all dogs were stable and they had no observable disease.

Since no differences were found in the GH responses between male and female dogs, data were pooled irrespective of sex.

\section{Experimental protocol}

All the experimental procedures were carried out in accordance with the protocol previously authorized by the Committee on Animal Care and Use of the University of Milan.

The GH-releasing effect of GHRH (GRF(1-29)- $\mathrm{NH}_{2}$, Geref, Serono, Rome, Italy) or HEXA (EP 23905, Europeptides, Argenteuil, France) was tested in each dog during an infusion of SS (Stilamin, Serono) or saline or after an i.v. dose of PZ (Gastrozepin, BoehringerIngelheim, Florence, Italy).
Every test was performed in the same dogs under fed or fasting conditions, following a randomized order with an interval of at least one month between two successive tests.

After the first test in fed dogs had been performed (see below), a 2-day complete fast with water available ad libitum was imposed and, on the morning of the 3rd day, when dogs were still fasting, the previous test was repeated.

The following tests were performed.

\section{Saline or SS and saline, GHRH, HEXA or GHRH plus HEXA}

Starting at $0900 \mathrm{~h}$ on the experimental day, an indwelling, non-thrombogenic intravenous catheter (Venisystem Butterfly-10, Abbott Ireland Ltd, Sligo, Republic of Ireland) was positioned in the cephalic vein and fixed with an adhesive bandage.

A solution of $0.9 \%$ saline was infused $(5 \mathrm{ml} / \mathrm{h})$ from $0900 \mathrm{~h}$ to $1230 \mathrm{~h}$. In other studies, a solution of $0.9 \%$ saline was delivered $(5 \mathrm{ml} / \mathrm{h})$ from $0900 \mathrm{~h}$ to $0930 \mathrm{~h}$, then an i.v. infusion of 4 or $8 \mu \mathrm{g} / \mathrm{kg} / \mathrm{h}$ SS was started $(5 \mathrm{ml} / \mathrm{h})$ and continued until $1230 \mathrm{~h}$. During saline or SS infusion, at $1130 \mathrm{~h}, \mathrm{GHRH}(2 \mu \mathrm{g} / \mathrm{kg}$ i.v. $)$ or HEXA $(250 \mu \mathrm{g} / \mathrm{kg}$ i.v.) or GHRH plus HEXA was administered.

Doses were selected on the basis of previous doseresponse experiments with either GHRH (S G Cella, unpublished results) or HEXA (Cella et al. 1995).

Because the GH response to GHRH was completely inhibited in fed dogs by the lower dose of SS (see below), the infusion of the higher SS dose and the ensuing GHRH test were performed only in fasted dogs.

For GH evaluation, blood samples $(1 \mathrm{ml})$ were withdrawn every $30 \mathrm{~min}$ from $0900 \mathrm{~h}$ to $1130 \mathrm{~h}$, then every $15 \mathrm{~min}$ from $1130 \mathrm{~h}$ to $1230 \mathrm{~h}$. For SS evaluation, blood samples $(5 \mathrm{ml})$ were withdrawn at $0900 \mathrm{~h}, 0930 \mathrm{~h}, 1130 \mathrm{~h}$ and $1200 \mathrm{~h}$. In each dog, a total of about $30 \mathrm{ml}$ blood was removed.

\section{$P Z$ and GHRH and/or HEXA}

PZ $(0.6 \mathrm{mg} / \mathrm{kg}$ i.v.) was administered $5 \mathrm{~min}$ before GHRH $(2 \mu \mathrm{g} / \mathrm{kg}$ i.v. $)$, HEXA ( $250 \mu \mathrm{g} / \mathrm{kg}$ i.v. $)$ or GHRH plus HEXA. Blood samples $(1 \mathrm{ml})$ were collected before GHRH or HEXA or GHRH plus HEXA $(-15$ and 0$)$ and every $15 \mathrm{~min}$ until $60 \mathrm{~min}$ post-peptide injection. In each dog a total of about $6 \mathrm{ml}$ blood was removed.

\section{Metabolic clearance rate of somatostatin}

The metabolic clearance rate (MCR) of SS in all dogs in fasting and fed states was calculated by the method of Tait (1963) from the following equation: $\mathrm{MCR}=$ (infusion rate of SS) $/($ (steady-state levels of SS)-preinfusion levels). Preinfusion levels of SS were determined as the mean of SS concentrations in the $0900 \mathrm{~h}$ and $0930 \mathrm{~h}$ samples and 
steady-state levels of SS were determined as the mean of SS concentrations in the $1130 \mathrm{~h}$ and $1200 \mathrm{~h}$ samples, i.e. 120 and $150 \mathrm{~min}$ after starting the infusion. The infusion rate of SS was $4 \mu \mathrm{g} / \mathrm{kg} / \mathrm{h}$.

\section{GH radioimmunoassay}

Blood was collected into tubes containing EDTA and immediately chilled. Plasma was frozen until assayed for $\mathrm{GH}$ by a double-antibody radioimmunoassay. Highly purified canine GH (batch AFP 1983b, Pituitary Hormones and Antisera Centre, Torrance, CA, USA), obtained through the courtesy of Dr A F Parlow, was used for radioiodination and as a standard. The assay sensitivity was $0.5 \mathrm{ng} / \mathrm{ml}$. The intra-assay coefficients of variation were $3 \cdot 8$ and $4 \cdot 1 \%$ at concentrations of 12.5 and $3 \cdot 1 \mathrm{ng} / \mathrm{ml}$ respectively. To avoid possible interassay variation, all samples of a given experiment were assayed in a single RIA.

\section{SS radioimmunoassay}

Blood samples were collected in $1.4 \mathrm{mg} / \mathrm{ml} \mathrm{Na}_{2}$ EDTA and $1000 \mathrm{kIU} / \mathrm{ml}$ aprotinin (Antagosan, Istituto Behring, Scoppito, Italy). Octadecylsilylsilica cartridges (Sep-Pak $\mathrm{C}_{18}$, Waters Co. Inc., Milford, MA, USA) were prepared by washing with $5 \mathrm{ml}$ acetonitrile (Sigma Chemical Co., St Louis, MO, USA) followed by $5 \mathrm{ml}$ water. Dog plasma $(2.0 \mathrm{ml})$ was applied. Weakly bound plasma components were eluted with $5 \mathrm{ml}$ water followed by $5 \mathrm{ml}$ $0 \cdot 1 \%$ trifluoroacetic acid (TFA, Aldrich Chemical Co., Milwaukee, WI, USA). Somatostatin was eluted with $2 \cdot 0 \mathrm{ml}$ 80:20 (v/v) acetonitrile:0·1\% TFA. The eluate was promptly shell frozen, lyophilized and stored at $-80^{\circ} \mathrm{C}$ until subsequent assay.

The lyophilized eluates were reconstituted in $2.0 \mathrm{ml}$ phosphate buffer $0.05 \mathrm{M}, \mathrm{pH} 7 \cdot 2$, containing $0.01 \mathrm{M}$ EDTA and $0 \cdot 3 \%$ BSA. Somatostatin RIA was performed using radiolabeled SS $\left(3-\left[{ }^{125} \mathrm{I}\right]\right.$ iodotyrosy $1^{11} ; \mathrm{Tyr}^{11}-$ somatostatin-14), rabbit antiserum to SS (code N. 1611) and standard SS (somatostatin-14) supplied from Amersham Italia s.r.l., Milan, Italy. The assay sensitivity was $20 \mathrm{fmol} / \mathrm{ml}$ and the intra-assay variation was $8 \%$. To avoid interassay variation all samples were assayed simultaneously.

\section{Statistical analysis}

$\mathrm{GH}$ values were expressed either as mean area under the plasma concentration vs time curves $\left(\mathrm{AUC}_{0-60} ; \mathrm{ng} / \mathrm{ml} /\right.$ h) \pm s.E.M., calculated by the trapezoidal integration, or as absolute mean values $(\mathrm{ng} / \mathrm{ml}) \pm$ s.E.M. Somatostatin concentrations were expressed as absolute mean values (fmol/ $\mathrm{ml}) \pm$ s.E.M. Since no differences in hormonal levels between male and female dogs were observed in the different experimental conditions, data were pooled.

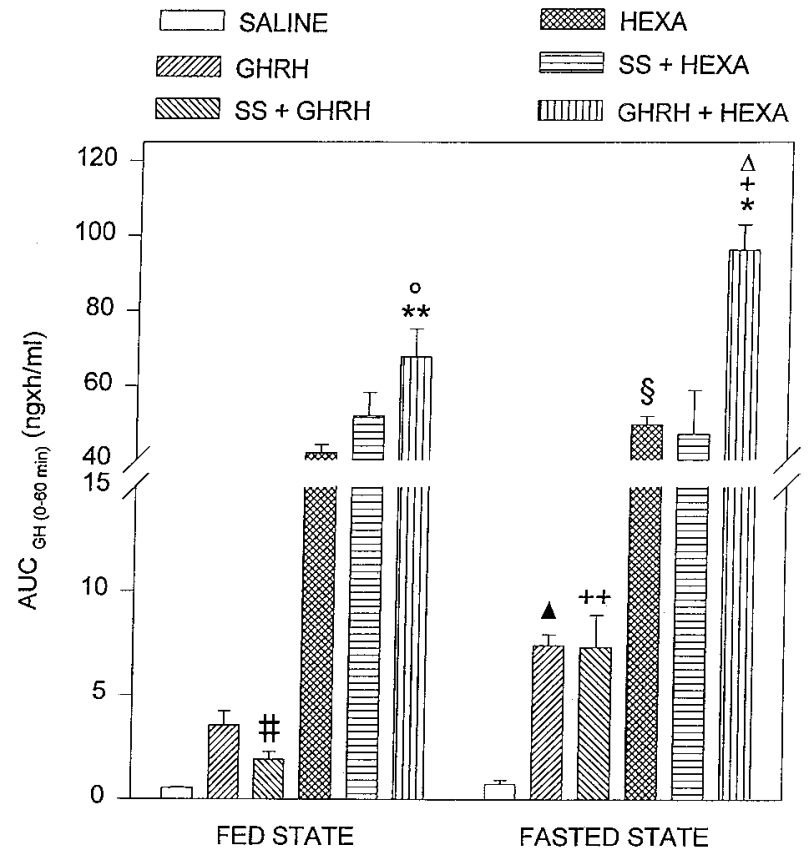

Figure 1 Integrated $\mathrm{GH}$ responses to saline, GHRH, HEXA and GHRH plus HEXA during saline or SS infusion $(4 \mu \mathrm{g} / \mathrm{kg} / \mathrm{h})$ in 10 beagle dogs before and after a 2-day fast. See text for further details. $\# P<0.05$ vs GHRH in the fed state; ${ }^{\circ} P<0.01$ vs HEXA in the fed state; ${ }^{* *} P<0.01$ vs GHRH in the fed state; $\boldsymbol{\Delta} P<0 \cdot 01$ vs GHRH in the fed state; $++P<0 \cdot 01$ vs SS + GHRH in the fed state; $\S P<0.05$ vs HEXA in the fed state; $\triangle P<0.01$ vs HEXA in the fasting state; $+P<0.01$ vs GHRH in the fasting state; ${ }^{*} P<0.01$ vs GHRH+HEXA in the fed state.

Statistical comparisons of the mean values were performed by the $t$-test for unpaired or paired (where necessary) data, preceded by analysis of variance (ANOVA). A $P$ value $<0.05$ was taken to be statistically significant.

\section{Results}

Saline

Fed state During saline infusion the plasma GH concentrations remained stable over the entire experimental period and were near the detection limit of our assay (peak plasma GH, $0 \cdot 7 \pm 0 \cdot 2 \mathrm{ng} / \mathrm{ml}$ ) (Figs 1 and 2).

Fasting state Fasting increased, though not significantly, the plasma GH levels (peak plasma GH, $1.6 \pm 0.6 \mathrm{ng} / \mathrm{ml}$; $P=\mathrm{NS}$ vs saline in fed state) (Figs 1 and 2 ).

\section{GHRH}

Fed state Administration of GHRH was followed by an unequivocal rise in plasma $\mathrm{GH}$ (peak plasma $\mathrm{GH}, 8 \cdot 3 \pm$ $1.5 \mathrm{ng} / \mathrm{ml}$ ). Plasma $\mathrm{GH}$ concentrations peaked at about $15 \mathrm{~min}$ and then decreased to baseline within $60 \mathrm{~min}$. 


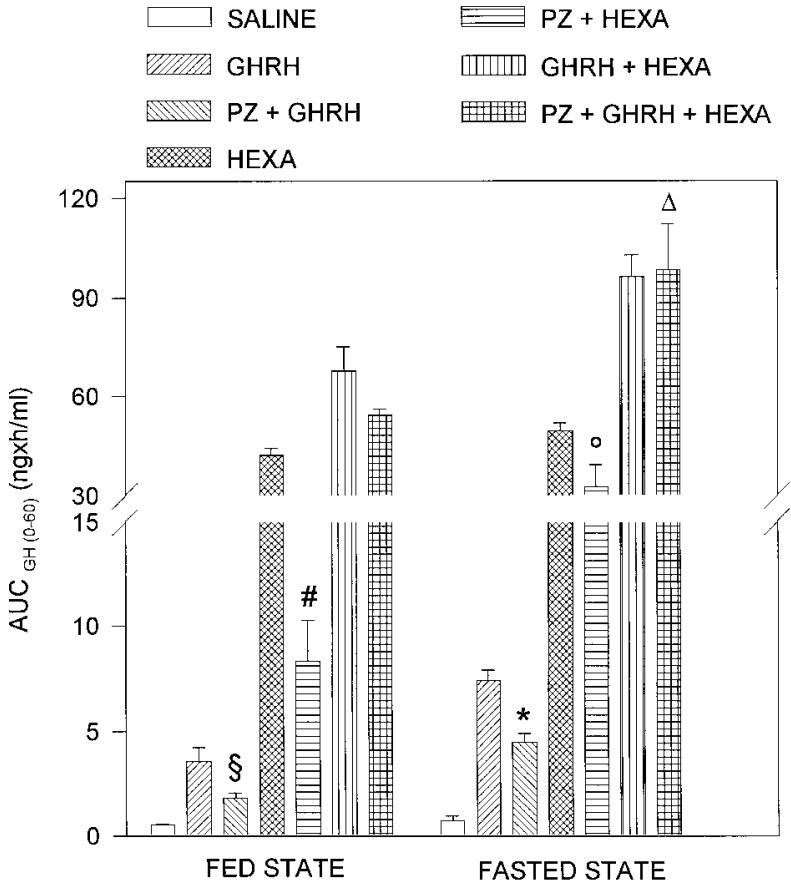

Figure 2 Integrated $\mathrm{GH}$ responses to saline, GHRH, HEXA and GHRH plus HEXA in 10 beagle dogs during saline or after pretreatment with $\mathrm{PZ}$, before and after a 2-day fast. See text for further details. $\S P<0.05$ vs $G H R H$ in the fed state; $\# P<0.01$ vs HEXA in the fed state; ${ }^{*} P<0.01$ vs $P Z+G H R H$ in the fed state; ${ }^{\circ} P<0.01$ vs $\mathrm{PZ}+\mathrm{HEXA}$ in the fed state; $\triangle P<0.01$ vs $\mathrm{PZ}+\mathrm{GHRH}$ + HEXA in the fed state.

Fasting state The GHRH bolus induced a rise in plasma GH levels, significantly higher than that observed during the fed state (peak plasma GH, $12 \cdot 5 \pm 1 \cdot 7 \mathrm{ng} / \mathrm{ml} ; P<0 \cdot 01$ ) (Fig. 1).

\section{SS and GHRH}

Fed state Infusion of the lower dose of SS suppressed the GH-releasing effect of GHRH in all dogs (peak plasma $\mathrm{GH}, 2.5 \pm 0.8 \mathrm{ng} / \mathrm{ml} ; P<0.05$ vs GHRH in fed state) (Fig. 1).

Fasting state When the lower dose of SS was infused, administration of GHRH was followed in all dogs by a robust $\mathrm{GH}$ burst (peak plasma $\mathrm{GH}, 11 \cdot 4 \pm 2.6 \mathrm{ng} / \mathrm{ml}$ ), which was significantly higher than that observed in the same dogs when fed ad libitum $(P<0 \cdot 01)$ (Fig. 1) and superimposable on that induced by GHRH alone during fasting $(P=\mathrm{NS})$ (Fig. 1). The GH response to GHRH was still of the same magnitude when the higher dose of SS was infused (peak plasma $\mathrm{GH}, 9 \cdot 6 \pm 2.3 \mathrm{ng} / \mathrm{ml} ; P=\mathrm{NS}$ vs GHRH in fasting state; $P=\mathrm{NS}$ vs the lower dose of SS and GHRH in fasting state) (data not shown).

\section{$P Z$ and GHRH}

Fed state GHRH bolus injection did not induce any GH response when dogs were pretreated with PZ (peak plasma $\mathrm{GH}, 2 \cdot 2 \pm 0 \cdot 4 \mathrm{ng} / \mathrm{ml} ; P<0 \cdot 05$ vs $\mathrm{GHRH}$ in fed state) (Fig. 2).

Fasting state GHRH bolus injection was followed by a small, but unequivocal GH rise in dogs pretreated with $\mathrm{PZ}$ $(P<0 \cdot 01$ vs $\mathrm{PZ}$ and GHRH in fed state) (Fig. 2). Plasma $\mathrm{GH}$ concentrations peaked at about $15 \mathrm{~min}$ and then decreased to baseline values within $60 \mathrm{~min}$ (peak plasma $\mathrm{GH}, 7 \cdot 8 \pm 1 \cdot 1 \mathrm{ng} / \mathrm{ml})$.

\section{HEXA}

Fed state Administration of HEXA was followed by a striking rise in plasma GH concentrations (peak plasma $\mathrm{GH}, 59 \cdot 3 \pm 3.3 \mathrm{ng} / \mathrm{ml}$ ). The mean plasma $\mathrm{GH}$ response (Fig. 1) was significantly higher after HEXA than after GHRH administration. Plasma GH concentrations peaked at about $15 \mathrm{~min}$ and then decreased to baseline values within about $60 \mathrm{~min}$.

Fasting state Administration of HEXA in the fasted state induced only a slight increase in plasma $\mathrm{GH}$ concentrations over that which it elicited in the fed state $(P<0 \cdot 05)$ (Fig. 1). The peak plasma $\mathrm{GH}$ value was $60 \cdot 6 \pm 2 \cdot 3 \mathrm{ng} / \mathrm{ml}$.

\section{SS and HEXA}

Fed state The lower dose of SS failed to suppress the GH response to HEXA (peak plasma GH, 91.4 $\pm 11 \cdot 1 \mathrm{ng} / \mathrm{ml}$; $P=\mathrm{NS}$ vs HEXA in the fed state) (Fig. 1), while the higher SS dose only partially did so (peak plasma $\mathrm{GH}$, $38 \cdot 8 \pm 11 \cdot 3 \mathrm{ng} / \mathrm{ml} ; P<0 \cdot 01$ vs HEXA in the fed state) (Fig. 3).

Fasting state The lower dose of SS failed to suppress the GH-releasing effect of HEXA (peak plasma GH, $83 \cdot 8 \pm 20.9 \mathrm{ng} / \mathrm{ml} ; P=\mathrm{NS}$ vs HEXA in the fasting state; $P=$ NS vs the lower SS dose and HEXA in the fed state) (Fig. 1), whereas the higher SS dose reduced, but did not abolish, the GH response to HEXA (peak plasma GH, $33.0 \pm 9.6 \mathrm{ng} / \mathrm{ml} ; P<0.01$ vs HEXA in the fasting state) (Fig. 3).

\section{$P Z$ and HEXA}

Fed state Pretreatment with PZ markedly reduced the GH response to HEXA (peak plasma $\mathrm{GH}, 20 \cdot 0 \pm$ $6.6 \mathrm{ng} / \mathrm{ml} ; P<0 \cdot 01$ vs HEXA in the fed state) (Fig. 2).

Fasting state The inhibition exerted by $\mathrm{PZ}$ on the GH-releasing effect of HEXA was markedly reduced by 


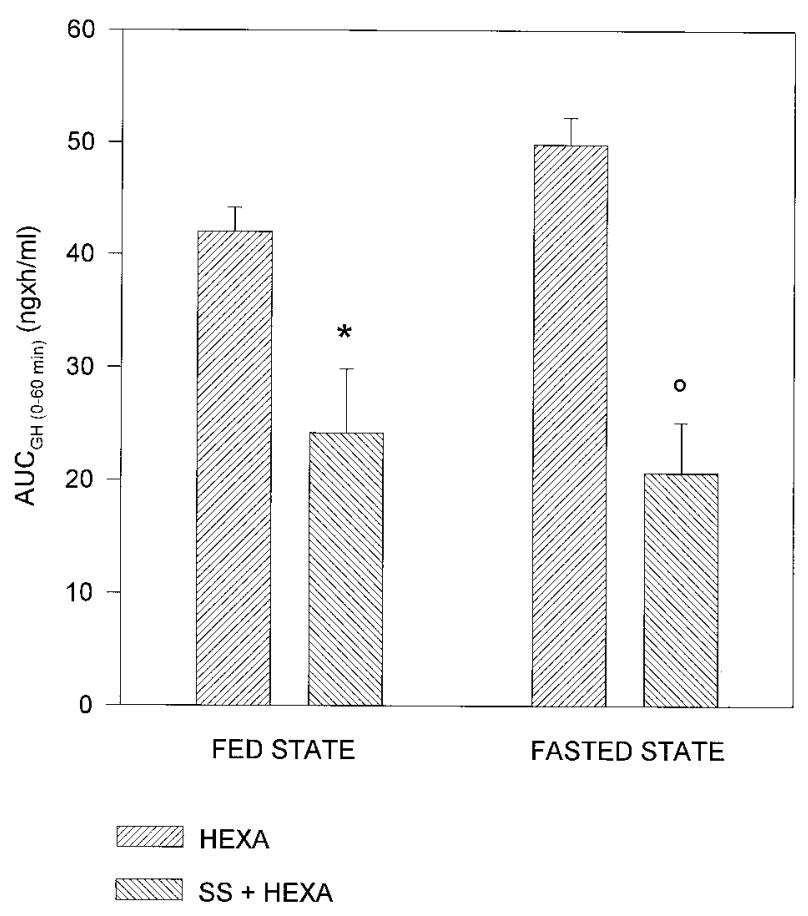

Figure 3 Integrated GH responses to HEXA during saline or SS infusion $(8 \mu \mathrm{g} / \mathrm{kg} / \mathrm{h})$ in 10 beagle dogs before and after a 2-day fast. See text for further details. ${ }^{*} P<0 \cdot 01$ vs HEXA in the fed state; ${ }^{\circ} P<0.01$ vs HEXA in the fasting state.

fasting ( $P<0.01 \mathrm{vs}$ PZ and HEXA in the fed state) (Fig. 2). The peak plasma $\mathrm{GH}$ value was $52 \cdot 7 \pm 13.8 \mathrm{ng} / \mathrm{ml}$ at $15 \mathrm{~min}$.

\section{GHRH plus HEXA}

Fed state Co-administration of HEXA plus GHRH induced a higher GH response (peak plasma GH, $119 \cdot 2 \pm 7 \cdot 9 \mathrm{ng} / \mathrm{ml})$ than HEXA alone $(P<0 \cdot 01)$ or GHRH alone $(P<0 \cdot 01)$ and also higher than the sum of the individual $\mathrm{GH}$ responses $(P<0 \cdot 01)$ (Fig. 1).

Fasting state The GH response to combined administration of the peptides further increased during fasting (peak plasma GH, $153 \cdot 1 \pm 16 \cdot 8 \mathrm{ng} / \mathrm{ml} ; \quad P<0 \cdot 01$ vs GHRH plus HEXA in the fed state; $P<0 \cdot 01$ vs GHRH in the fasting state; $P<0.01$ vs HEXA in the fasting state; $P<0 \cdot 01$ vs the sum of the individual $G H$ responses to GHRH alone and HEXA alone in the fasting state) (Fig. 1).

\section{$P Z$ and GHRH plus HEXA}

Fed state Pretreatment with PZ only slightly inhibited the robust $\mathrm{GH}$ burst elicited by combined administration of GHRH plus HEXA (peak plasma GH, 66.49 $\pm 6 \cdot 2 \mathrm{ng}$ / $\mathrm{ml} ; P<0 \cdot 01$ vs $P Z$ and GHRH in the fed state; $P<0 \cdot 01$ vs
PZ and HEXA in the fed state; $P=\mathrm{NS}$ vs GHRH plus HEXA in the fed state) (Fig. 2).

Fasting state Pretreatment with PZ failed to suppress the GH response to combined administration of GHRH plus HEXA (peak plasma GH, 142.5 $\pm 25.5 \mathrm{ng} / \mathrm{ml}$; $P<0.01$ vs $\mathrm{PZ}$ and GHRH plus HEXA in the fed state; $P<0 \cdot 01$ vs $P Z$ and GHRH in the fasting state; $P<0 \cdot 01$ vs $\mathrm{PZ}$ and HEXA in the fasting state; $P=\mathrm{NS}$ vs $\mathrm{GHRH}$ plus HEXA in the fasting state) (Fig. 2).

\section{Metabolic clearance rate of somatostatin}

Calculation of the MCR of SS showed no significant differences in dogs during the fed or fasting state $(96 \cdot 8 \pm 8 \cdot 9$ vs $94 \cdot 2 \pm 9 \cdot 8 \mathrm{ml} / \mathrm{min} / \mathrm{kg}, P=\mathrm{NS})$.

\section{Adverse effects}

No particular adverse effects were noticed in any test except for a slight tachycardia in dogs pretreated with PZ.

\section{Discussion}

GH secretion is increased by fasting in mammals, including man (Ho et al. 1988, Hartman et al. 1992b), the only notable exception being the rat in which GH secretion decreases with fasting (Tannenbaum \& Rorstad 1979).

In young beagle dogs, we have previously demonstrated that a 5-day fast increased $\mathrm{GH}$ peak frequency and amplitude, integrated concentration of GH and total peak area evaluated during a 6-h period (Cella et al. 1989). An increased frequency of GHRH release with prolonged periods of reduced SS secretion was surmised from the profile of GH secretion in animals (Cella et al. 1989, 1996a) and humans (Hartman et al. 1992b) during fasting.

Serum insulin-like growth factor (IGF)-I levels were unchanged in young dogs undergoing a 5-day fast (Cella et al. 1989). It must be recalled, however, that levels of IGF-binding protein-1 are increased by fasting (Busby et al. 1988, Murphy et al. 1991) and this may decrease the bioavailable portion of IGF-I, thus reducing IGF-I negative feedback on GH secretion (Müller 1987), before changes in total serum levels of IGF-I may occur.

The functional activation of somatotropic function elicited by fasting may be relevant for providing information on the still elusive mechanism(s) underlying the strong GH-releasing effect of HEXA (Bowers et al. 1991, Korbonits \& Grossman 1995). This discussion may, additionally, encompass some aspects of somatotropic regulation in AN, a disease which, from a purely metabolic viewpoint, can be reminiscent of the dog model of calorie restriction (Müller et al. 1995). 
In our study, as expected, a 2-day fast strikingly enhanced the GHRH-induced GH release in young dogs; this pattern was not mimicked by HEXA, the administration of which was followed by a GH rise similar to that present in the fed state. A priming action exerted by secretory bursts of GHRH of enhanced amplitude/ frequency, coupled to a diminished somatostatinergic tone (Ho et al. 1988, Hartman et al. 1992b) may readily account for the exaggerated $\mathrm{GH}$ response to GHRH in fasted dogs.

The 'reduced' increase in the GH response to HEXA is more difficult to interpret. HEXA proved capable of priming its own GH-releasing action in an early phase of a long-term treatment in old dogs; this initial priming was then followed by a drop in HEXA-induced GH release below pretreatment values (Cella et al. 1996b). The most likely hypothesis was that chronic administration of the peptide had down-regulated GHRP receptors (Howard et al. 1996). Based on these observations, it is tempting to speculate that, for analogy, the relatively weak increase in the HEXA-stimulated GH rise in fasted dogs may result from down-regulation resulting in sustained release of an endogenous GHRP ligand (Korbonits \& Grossman 1995, Howard et al. 1996). Interestingly, an absolute or relatively weaker GH-releasing activity of HEXA compared with GHRH has been reported recently in two independent studies in patients with AN (Foppiani et al. 1996, Scacchi et al. 1996).

Coupling of endogenous GHRH secretion with the exogenously administered GHRH would also explain why the $\mathrm{GH}$ response to GHRH plus HEXA of fed dogs (Bowers et al. 1990, Cella et al. 1995) was enhanced by fasting.

In fasted dogs (Cella et al. 1989, 1996a, Arce et al. 1991) or in patients with AN (Müller et al. 1995), increased GH secretion may be the result not only of an enhanced GHRH and/or diminished somatostatinergic tone (see above), but complete or partial pituitary refractoriness to SS, released from the hypothalamus, may also contribute. This hypothesis was substantiated in our study by the finding that SS, infused at a dose which reduced the GHRH-induced GH rise in fed dogs by about $50 \%$, failed to do the same in fasted dogs given a GHRH bolus. Similar SS metabolic clearance rates in fed and fasted dogs make it unlikely that different pharmacokinetics of the infused peptide are involved.

In fasting rats a significant decrease of SS receptor mRNA expression, which sensitizes the pituitary responsiveness to an ensuing GHRH stimulus, has been reported (Tannenbaum et al. 1989, Bruno et al. 1994). This event, however, is probably due to a fasting-induced activation of hypothalamic somatostatinergic function and downregulation of pituitary receptors, since in the rat fasting suppresses GH secretion (Tannenbaum \& Rorstad 1979, Bruno et al. 1994). Such a mechanism is unlikely to occur in the dog and other mammals, including humans, where fasting induces $\mathrm{GH}$ hypersecretion (see above).
To the best of our knowledge, this is the first report of somatotrope refractoriness to SS in the GHRH test during fasting, a finding corroborated by the use of SS at doses able fully to counteract the $\mathrm{GH}$ rise induced by GHRH (Cella et al. 1996a). Irrespective of the underlying mechanism(s) of action, this refractoriness may contribute to GH hypersecretion and the enhanced somatotrope responsiveness to GHRH of fasting mammals (Cella et al. 1989, Arce et al. 1991) or AN patients (Müller et al. 1995).

In agreement with previous data in humans (Arvat et al. 1995), the GH-releasing activity of HEXA was partially refractory to modulation by SS in both fed and fasted dogs. In fact, in both conditions only the higher dose of SS reduced the GH response to HEXA.

At present we do not know why, in fasted dogs, the higher SS dose was still capable of reducing the $\mathrm{GH}$ response to HEXA, but not that to GHRH. Irrespective of a sound interpretation of this finding, this pattern once again underlines the different mechanisms of actions of the two peptides.

Based on both animal (Casanueva et al. 1983, Locatelli et al. 1986, Torsello et al. 1988) and human studies (Massara et al. 1986, Ross et al. 1987) it is now a tenet of the GH neuroendocrine control that muscarinic cholinergic agonists and antagonists act to inhibit or stimulate, respectively, hypothalamic somatostatinergic function and, in this way, modulate the action of CNS- or pituitaryacting GH secretagogues. Thus, in humans atropine, a muscarinic cholinergic antagonist, or PZ, a more selective antagonist of muscarinic M1 receptors (Watson et al. 1983), were able to suppress the GH release elicited by insulin hypoglycemia (Blackard \& Waddel 1969), arginine (Casanueva et al. 1984) or GHRH (Massara et al. 1984), while conversely, pyridostigmine, an acetylcholinesterase (Ach-E) inhibitor, greatly enhanced the GH release elicited by GHRH (Massara et al. 1986, Ross et al. 1987). Studies in both animals (Torsello et al. 1988) and humans (Ross et al. 1987) have also disclosed an important cholinergic link in the feedback action of $\mathrm{GH}$, involving SS release.

However, some observations in the sheep, where a single administration of neostigmine, an Ach-E inhibitor, stimulated GHRH release into hypophysial portal blood without changes in SS levels (Magnan et al. 1993, 1995), challenge the view of a reciprocal and univocal relationship between SS function and the hypothalamic cholinergic system.

Further uncertainties in this context also stem from our study. Although, as already reported in calorie-restricted dogs (Arce et al. 1991) and in patients with AN (Tamai et al. 1990, Rolla et al. 1991), PZ failed to inhibit completely the GHRH-induced rise as it did in fed controls, there was, nevertheless, with $\mathrm{PZ}$ in the fasted dogs of our study a consistent suppression of the GHRHinduced GH release. This contrasted sharply with the total 
ineffectiveness of a sustained infusion of SS to alter, under the same experimental conditions, the stimulatory effect of GHRH.

These data do not exclude the possibility that PZ may act via endogenous release of the SS-28 from the hypothalamus, which is more effective in portal blood, compared with the SS-14 given peripherally (Srikant \& Patel 1982). However, SS and PZ effects were even more divorced in the HEXA study: in contrast to the limited ability of SS to suppress the HEXA-elicited GH rise, PZ vigorously counteracted the $\mathrm{GH}$ rise induced by the hexapeptide.

Although PZ may possibly act via stimulation of somatostatinergic function, our findings imply that it may also inhibit GHRH neurones. It is of note in this context that $\mathrm{PZ}$ was less effective in inhibiting the GH response to HEXA during fasting or to combined administration of HEXA plus GHRH in the fed and fasting states. In such experimental conditions, GHRH function was either endogenously activated (fasting) or was provided exogenously (HEXA plus GHRH in the fed state).

Consistent with our last results, Peñalva et al. (1993) have shown in normal volunteers that atropine was able to prevent the GH responses to GHRH or GHRP-6 alone, but did not completely abolish the GH response to combined administration of GHRH and GHRP-6. Coexistence of Ach and GHRH in nerve terminals of the rat median eminence (Meister 1989) are supportive of our view.

In conclusion, evaluation of the GH-releasing activity of GHRH, HEXA or either peptide in fed and fasted young beagles evidenced profound differences in the way they influence somatotropic function under physiological conditions or in response to pharmacological stimuli. This has to be considered when devising therapeutic strategies with GHRH alone, HEXA alone or combined peptide administration.

In addition, the different ability of $\mathrm{PZ}$ and $\mathrm{SS}$ in inhibiting GHRH action challenges the tenet that muscarinic cholinergic compounds modulate exclusively somatostatinergic function; it implies, instead, an action also mediated by GHRH.

\section{References}

Akman MS, Girard M, O’Brien LF, Ho AK \& Chik CL 1993 Mechanisms of action of a second generation growth hormone-releasing peptide (Ala-His-D-beta-Nal-Ala-Trp-D-PheLys-NH2) in rat anterior pituitary cells. Endocrinology 132 1286-1291.

Arce V, Cella SG, Locatelli V \& Müller EE 1991 Studies of growth hormone secretion in calorically restricted dogs: effect of cholinergic agonists and antagonists, glucose and thyrotrophin-releasing hormone. Neuroendocrinology 53 467-472.

Arvat E, Gianotti L, Di Vito L, Imbimbo BP, Lenaerts V, Deghenghi R, Camanni F \& Ghigo E 1995 Modulation of growth hormonereleasing activity of hexarelin in man. Neuroendocrinology 61 51-56.
Blackard WG \& Waddel CC 1969 Cholinergic blockade and growth hormone responsiveness to insulin hypoglycemia. Proceedings of the Society for Experimental Biology and Medicine 131 192-196.

Bowers CY, Momany FA, Reynolds GA \& Hong A 1984 On the in vitro and in vivo activity of a new synthetic hexapeptide that acts on the pituitary to specifically release growth hormone. Endocrinology 114 1537-1545.

Bowers CY, Reynolds GA, Durham D, Barrera CM, Pezzoli SS \& Thorner MO 1990 Growth hormone (GH)-releasing peptide stimulates $\mathrm{GH}$ release in normal men and acts synergistically with GH-releasing hormone. Journal of Clinical Endocrinology and Metabolism 70 975-982.

Bowers CY, Sartor AO, Reynolds GA \& Badger TM 1991 On the actions of the growth hormone-releasing hexapeptide, GHRP. Endocrinology 128 2027-2035.

Bowers CY, Alster DK \& Frentz JM 1992 The growth hormonereleasing activity of a synthetic hexapeptide in normal men and short statured children after oral administration. Journal of Clinical Endocrinology and Metabolism 74 292-298.

Bruno JF, Xu Y, Song J \& Berelowitz M 1994 Pituitary and hypothalamic somatostatin receptor subtype messenger ribonucleic acid expression in the food-deprived and diabetic rat. Endocrinology 135 1787-1792.

Busby WH, Snyder DK \& Clemmons DR 1988 Radioimmunoassay of 26000 -dalton plasma insulin-like growth factor-binding protein: control by nutritional variables. Journal of Clinical Endocrinology and Metabolism 67 1225-1230.

Casanueva FF, Betti R, Cella SG \& Müller EE 1983 Effect of agonists and antagonists of cholinergic neurotransmission on growth hormone release in the dog. Acta Endocrinologica 103 15-20.

Casanueva FF, Villenueva L, Cabranes JA, Cabezas-Cerrato J \& Fernandez-Cruz A 1984 Cholinergic mediation of growth hormone secretion elicited by arginine, clonidine and physical exercise in man. Journal of Clinical Endocrinology and Metabolism 59 526-530.

Cella SG, Moiraghi V, Minuto F, Barreca A, Cocchi D, De Gennaro Colonna V, Reina G \& Müller EE 1989 Prolonged fasting or clonidine can restore the defective growth hormone secretion in old dogs. Acta Endocrinologica 121 177-184.

Cella SG, Locatelli V, Poratelli M, De Gennaro Colonna V, Imbimbo BP, Deghenghi R \& Müller EE 1995 Hexarelin, a potent GHRP analogue: interactions with GHRH and clonidine in young and aged dogs. Peptides 16 81-86.

Cella SG, Luceri M, Cattaneo L, Torsello A \& Müller EE 1996a Somatostatin withdrawal as generator of pulsatile GH release in the dog: a possible tool to evaluate the endogenous GHRH tone? Neuroendocrinology 3 481-488.

Cella SG, Cerri CG, Daniel S, Sibilia V, Rigamonti A, Cattaneo L, Deghenghi R \& Müller EE 19966 Sixteen weeks of hexarelin therapy in aged dogs: effect on the somatotropic axis, muscle morphology, and bone metabolism. Journal of Gerontology $\mathbf{5 1}$ 439-447.

Deghenghi R, Cananzi MM, Torsello A, Battisti C, Müller EE \& Locatelli V 1994 GH-releasing activity of hexarelin, a new growth hormone releasing peptide, in infant and adult rats. Life Sciences $\mathbf{5 4}$ 1321-1328.

Foppiani L, Giusti M, Cuttica CM, Falivene MR, Valenti S \& Giordano G 1996 Hexarelin is a stronger GH-releasing peptide than GHRH in normal cycling women but not in anorexia nervosa. In Abstract Book of the International Congress of Endocrinology, June 12-15 1996, San Francisco, USA. Abstract P1-606, 286.

Ghigo E, Arvat E, Gianotti L, Imbimbo BP, Lenaerts V, Deghenghi R \& Camanni F 1994 Growth hormone-releasing activity of hexarelin, a new synthetic hexapeptide, after intravenous, subcutaneous, and oral administration in man. Journal of Clinical Endocrinology and Metabolism 78 693-698.

Goth MI, Lyons CE, Canny BJ \& Thorner MO 1992 Pituitary adenylate cyclase activating polypeptide, growth hormone 
(GH)-releasing peptide and GH-releasing hormone stimulate GH release through distinct pituitary receptors. Endocrinology 130 939-944.

Hartman ML, Farello G, Pezzoli SS \& Thorner MO 1992a Oral administration of growth hormone (GH)-releasing peptide stimulates $\mathrm{GH}$ secretion in normal men. Journal of Clinical Endocrinology and Metabolism 74 1378-1384.

Hartman M, Veldhuis JD, Johnson MI, Lee MM, Alberti KGMM, Samojlik E \& Thorner MO $1992 b$ Augmented GH secretory burst frequency and amplitude mediate enhanced GH secretion during a two-day fast in normal men. Journal of Clinical Endocrinology and Metabolism 74 757-765.

Ho KY, Veldhuis JD, Johnson ML, Furlanetto R, Evans WS, Alberti KG \& Thorner MO 1988 Fasting enhances growth hormone secretion and amplifies the complex rhythms of growth hormone secretion in man. Journal of Clinical Investigation 81 968-975.

Howard AD, Feighner SD, Cully DF, Arena JP, Liberator PA, Rosenblum CI, Hamelin M, Hrzeniuk DL, Palyha OC, Anderson J et al. 1996 A receptor in pituitary and hypothalamus that functions in growth hormone release. Science 273 974-977.

Ilson BE, Jorkasky DK, Curnow RT \& Stote RM 1989 Effect of a new synthetic hexapeptide to selectively stimulate growth hormone release in healthy human subjects. Journal of Clinical Endocrinology and Metabolism 69 212-214.

Korbonits M \& Grossman AB 1995 Growth hormone-releasing peptide and its analogues. Trends in Endocrinology and Metabolism 6 43-49.

Locatelli V, Torsello A, Redaelli M, Ghigo E, Massara F \& Müller EE 1986 Cholinergic agonist drugs modulate the growth hormone response to growth hormone releasing hormone in the rat: evidence for mediation by somatostatin. Journal of Endocrinology 111 271-275.

Lussier BT, French MB, Moor BC \& Kraicer J 1991 Free intracellular $\mathrm{Ca}^{2+}$ concentration $\left(\left[\mathrm{Ca}^{2+}\right]\right)$ and $\mathrm{GH}$ release from purified rat somatotrophs. Endocrinology 128 592-603.

Magnan E, Cataldi M, Guillaume V, Mazzocchi I, Dutour A, Conte-Devolx B, Giraud P \& Oliver C 1993 Neostigmine stimulates growth hormone releasing hormone release into hypophysial portal blood of conscious sheep. Endocrinology 132 1247-1251.

Magnan E, Mazzocchi I, Cataldi M, Guillaume V, Dutour A, Dadoun F, Le Bouc Y, Sauze N, Renard M, Conte-Devolx B \& Oliver C 1995 Effect of actively immunizing sheep against growth hormonereleasing hormone or somatostatin on spontaneous pulsatile and neostigmine-induced growth hormone secretion. Journal of Endocrinology 144 83-90.

Massara F, Ghigo E, Goffi S, Molinatti G, Müller EE \& Camanni F 1984 Blockade of hp-GRF-40-induced GH release in normal men by a cholinergic muscarinic antagonist. Journal of Clinical Endocrinology and Metabolism 59 1025-1027.

Massara F, Ghigo E, Molinatti P, Mazza E, Locatelli V, Müller EE \& Camanni F 1986 Potentiation of cholinergic tone by pyridostigmine bromide re-instates and potentiates the growth hormone responsiveness to intermittent administration of growth hormonereleasing factor in man. Acta Endocrinologica 113 12-16.

Meister B 1989 In Hypothalamic Neurosecretory Neurons. Histochemical and Experimental Studies on Distribution and Regulation with Special Reference to Multiple Messenger Systems. PhD Thesis, pp 600-601. Stockholm.

Molla F, Alvarez CV, Benitez L, Burguera B, Coya R, Casanueva FF \& Dieguez C 1993 Regulation of His-dTrp-Ala-Trp-dPhe-Lys$\mathrm{NH} 2$ (GHRP-6)-induced GH secretion in the rat. Neuroendocrinology 57 247-256.

Müller EE 1987 Neural control of somatotropic function. Physiological Reviews 67 962-1053.

Müller EE, Rolla M, Ghigo E, Belliti D, Arvat E, Andreoni A, Torsello A, Locatelli V \& Camanni F 1995 Involvement of brain catecholamines and acetylcholine in growth hormone hypersecretory states. Drugs $\mathbf{5 0} 805-837$.

Murphy LJ, Seneviratne C, Moreira P \& Reid RE 1991 Enhanced expression of insulin-like growth factor-binding protein-1 in the fasted rat: the effects of insulin and growth hormone administration. Endocrinology 128 689-696.

Peñalva A, Carballo A, Pombo M, Casanueva FF \& Dieguez C 1993 Effect of growth hormone (GH)-releasing hormone (GHRH), atropine, pyridostigmine, or hypoglycaemia on GHRP-6-induced secretion in man. Journal of Clinical Endocrinology and Metabolism 76 168-171.

Rolla M, Andreoni A, Belliti D, Ceragioli MR \& Paolicchi R 1986 Evaluation of growth hormone response to growth hormonereleasing factor in patients with anorexia nervosa. Psychiatry Research 16 Suppl 92.

Rolla M, Andreoni A, Belliti D, Cristofani R, Ferdeghini M \& Müller EE 1991 Blockade of cholinergic muscarinic receptors by pirenzepine and GHRH-induced GH secretion in the acute recovery phase of anorexia nervosa and atypical eating disorders. Biological Psychiatry 29 1079-1091.

Ross RJM, Tsagarakis S, Grossman A, Nhagafoong L, Tozel RJ, Rees LM \& Besser GM 1987 GH feedback occurs through modulation of hypothalamic somatostatin under cholinergic control: studies with pyridostigmine and GHRH. Clinical Endocrinology 27 727-732.

Scacchi M, Pincelli AI, Danesi \& Cavagnini F 1996 Growth hormone releasing activity of hexarelin in anorexia nervosa. In Abstract Book of the International Congress of Endocrinology, June 12-15 1996, San Francisco, USA. Abstract P3-66, 771.

Srikant CB \& Patel YC 1982 Characterization of pituitary membrane receptors for somatostatin in the rat. Endocrinology 110 2138-2144.

Tait PG 1963 The use of isotopic steroids for measurement of production rates in vivo. Journal of Clinical Endocrinology 23 1287-1297.

Tamai H, Komaki G, Matsubayashi S, Kobayashi N, Mori K, Nakagawa T, Truong MP, Walter RM Jr \& Kumagai LF 1990 Effect of cholinergic muscarinic receptor blockade of human growth hormone $(\mathrm{GH})$-releasing hormone (1-44)-induced GH secretion in anorexia nervosa. Journal of Clinical Endocrinology and Metabolism 70 738-741.

Tannenbaum GS \& Rorstad O 1979 Effect of prolonged food deprivation on the ultradian growth hormone rhythm and immunoreactive somatostatin tissue levels in the rat. Endocrinology 104 1733-1738.

Tannenbaum GS, Painson JC, Lengyel AM \& Brazeau P 1989 Paradoxical enhancement of pituitary growth hormone $(\mathrm{GH})$ responsiveness to $\mathrm{GH}$-releasing factor in the face of high somatostatin tone. Endocrinology 124 1380-1388.

Torsello A, Panzeri G, Cermenati P, Caroleo MC, Ghigo E, Camanni F \& Müller EE 1988 Involvement of somatostatin and cholinergic system in the mechanisms of growth hormone autofeedback regulation in the rat. Journal of Endocrinology 117 273-281.

Walker RF, Codd EE, Barone FC, Nelson AH, Goodwin T \& Campbell SA 1990 Oral activity of the growth hormone releasing peptide His-DTrp-Ala-Trp-DPhe-Lys-NH2 in rat, dogs, monkey. Life Sciences 47 29-36.

Watson M, Yamanuira HI \& Roeske WR 1983 A unique regulatory profile and regional distribution of $\left[{ }^{3} \mathrm{H}\right]$ pirenzepine binding in the rat provide evidence for distinct M1 and M2 muscarinic receptor subtypes. Life Sciences 32 3001-3011.

\section{Received 18 March 1997}

Revised manuscript received 20 August 1997

Accepted 24 September 1997 